\title{
PENGEMBANGAN MEDIA INTERAKTIF PADA MATA PELAJARAN DASAR LISTRIK KELAS X TEKNIK INSTALASI TENAGA LISTRIK SMK SWASTA IMELDA MEDAN
}

\author{
Tommi Daniel Hutajulu ${ }^{1}$, Sriadhi $^{2}$ \\ Jurusan Pendidikan Teknik Elektro, Fakultas Teknik Universitas Negeri Medan \\ 1tommidaniel64@gmail.com, ${ }^{2}$ sriadhi.sy@gmail.com
}

\begin{abstract}
This development research generally aims to (1) develop interactive multimedia-based learning media for Private Vocational School Imelda Medan, (2) to know the assessment of media experts and material experts on learning media, and (3) to know the feasibility of learning media based on the assessment of media experts and material experts. The method used in this research is Research and Development. This research was conducted at Imelda Private Vocational School Medan. Research and Development Results: (1) This development research process is carried out with several stages adapted from the borg and gall version development research model simplified into 4D. There are stages such as: Define, Design, Development, and Disseminate. Define stage includes definition, design stage includes storyboarding, development stage includes development of interactive multimedia-based learning media, validation of media experts and material experts, as well as revision of learning media from media experts and material experts and disseminate stage covering the trial stage. The target of this research is the Expert Lecturer of Medan State University. Testing of interactive multimedia by material validators showed that multimedia learning resulted both in material validation with an average score of 4.52 and for media validation with an average score of 4.59. Then obtained the conclusion that developed media is worth to use.
\end{abstract}

Keywords : Interactive Media, Interactive Multimedia

\begin{abstract}
Abstrak
Penelitian pengembangan ini secara umum bertujuan untuk (1) mengembangkan media pembelajaran berbasis multimedia interaktif untuk SMK Swasta Imelda Medan, (2) mengetahui penilaian ahli media dan ahli materi terhadap media pembelajaran, dan (3) mengetahui kelayakan media pembelajaran berdasarkan penilaian ahli media dan ahli materi . Metode yang digunakan pada penelitian ini adalah penelitian pengembangan (Research and Development ). Penelitian ini dilakukan di SMK Swasta Imelda Medan. Hasil Penelitian dan Pengembangan : (1) Proses Penelitian pengembangan ini dilaksanakan dengan beberapa tahapan yang diadaptasi dari model penelitian pengembangan versi borg and gall yang disederhanakan menjadi 4D. Adapaun tahapan tersebut yaitu : Define, Design, Development, dan Disseminate. Tahap define meliputi pendefenisian, tahap design meliputi pembuatan storyboard, tahap development meliputi pengembangan media pembelajaran berbasis multimedia interaktif, validasi ahli media dan ahli materi, serta revisi media pembelajaran dari ahli media dan ahli materi dan tahap disseminate meliputi tahap uji coba. Sasaran penelitian ini adalah Dosen Ahli Universitas Negeri Medan. Pengujian terhadap multimedia interaktif oleh validator materi menunjukan bahwa multimedia pembelajaran yang dihasilkan baik pada validasi materi dengan skor rata-rata 4.52 dan untuk validasi media dengan skor ratarata 4.59. Maka diperoleh kesimpulan media yang dikembangkan layak untuk digunakan.
\end{abstract}

\section{Kata kunci : Media Interaktif, Multimedia Interaktif}

\section{PENDAHULUAN}

Pengembangan media dalam pembelajaran sangat diperlukan untuk membantu guru dalam mengajar dan memudahkan siswa memahami materi yang disampaikan guru. Pengembangan media dalam proses pembelajaran dapat dilakukandengan menghubungkan berbagai macam media 
(teks,gambar,audio,video,animasi) dan salah satunya dapat menggunakan aplikasi atau software Macromedia Flash.

Menurut Fikri Alami (2006), macromedia flash merupakan suatu software yang dapat menampilkan ataupun membuat animasi -animasi dan bitmap yang sangat menarik seperti membuat animasi logo, movie, game, menu interaktif dan pembuatan aplikasi web serta perangkat ajar. Macromedia flash juga dilengkapi dengan action script (perintah tindakan) sehingga membuat persentasi atau perangkat agar menjadi lebih efektif dalam proses pembelajaran dikarenakan adanya perintah tindakan tersebut dan tentunya media pembelajaran tersebut menarik dibandingkan media pembelajaran lainnya. Dengan bantuan media interaktif macromedia flash dapat memudahkan guru untuk mengajak siswa berpartisipasi dan aktif dlam proses pembelajaran di kelas sehingga pembelajaran mejadi lebih efektif dalam proses pembelajaran dikarenakan adanya perintah tindakan tersebut dan tentunya media pembelajaran tersebut menarik dibanding media pembelajaran lainnya. Dengan bantuan media interaktif macromedia flash dapat memudahkan guru untuk mengajak siswa berpartisipasi dan aktif dalam proses pembelajaran dikelas sehingga pembelajaran menjadi lebih efektif karena tidak lagi berpusat pada guru serta tujuan pembelajaran dapat tersampaikan dan dicapai dengan baik sesuai dengan yang diharapkan.

Belajar dan pembelajaran sendiri merupakan suatu kesatuan yang tidak dapat dipisahkan lagi, dimana saat melakukan proses pembelajaran peserta didik melakukan kegiatan belajar. Kegiatan belajar ini merupakan sebuah kegiatan yang dirancang atau diatur untuk mempengaruhi perubahan tingkah laku peserta didik ke arah yang lebih baik melalui Informasi atau pengalaman peserta didik didapatkan melalui interaksi individu dengan individu dan individu dengan lingkungannya.

Media pembelajaran merupakan segala sesuatu yang digunakan oleh seorang pendidik untuk menyampaikan informasi berupa materi, bahan ajaran dan nasehat kepada peserta didik melalui beberapa media seperti radio, koran, buku, telefisi, komputer dan sebagainya, yang bertujuan untuk memperoleh pengetahuan, keterampilan dan sikap.

Media interaktif adalah media yang digunakan untuk menyajikan informasi secara menarik dan menyenangkan serta mudah dimengerti oleh siswa dalam memahami materi pembelajaran yang diberikan. Kelebihan multimedia interaktif sebagai media pembelajaran : Dapat digunakan sebagai sumber belajar mandiri dan kelompok. Sifanya yang interaktif memungkinkan siswa diajak untuk terlibat secara auditif,visual, dan kinatik, sehingga dengan keterlibatan siswa informasi, Memberikan iklim efektif individual, Daya tarik media dapat meningkatkan motivasi dalam mengikuti pembelajaran dan Sifatnya yang interaktif membuat pengguna dapat memahaminya lebih mudah.

Macromedia Flash 8 adalah sebuah program animasi yang telah banyak digunakan dalam pembuatan berbagai proyek animasi oleh para animator-animator professional. Diantara program-program animasi, program macromedia flash merupakan program yang paling fleksibel dalam pembuatan animasi (Madcoms,2006:30).

\section{METODE PENELITIAN}

Penelitian ini akan dilaksanakan di SMK Swasta Imelda Medan, JL. Bilal No. 24 Medan, Kelas X Teknik Instalasi Tenaga Listrik (TITL) pada semester Ganjil Tahun Ajaran 2019/2020. Objek penelitian adalah multimedia interaktif yang dikembangkan oleh peneliti untuk kompetensi dasar mengidentifikasi Dasar Listrik dan Elektromagnetik dengan materi teori dasar listrik.Sampel adalah bagian dari jumlah dan karakteristik yang dimiliki oleh populasi. Banyaknya sampel pada penelitian ini 30 orang siswa kelas X TITL SMK Swasta Imelda Medan. Berdasarkan judul penelitian yang diangkat oleh peneliti, jenis penelitian ini tergolong dalam penelitian pengembangan (development) atau dengan kata lain Research and Development ( $R$ \& D), yaitu pengembangan media pembelajaran interaktif . Metode penelitian yang digunakan untuk menghasilkan suatu produk, dan menguji kualitas dan keefektifan produk tersebut (Sugiyono, 2013:407). Penelitian ini menitik beratkan pada pengembangan media pembelajaran interaktif pada mata pelajaran Dasar Listrik dan Elektronika untuk siswa di sekolah menengah kejuruan. Siswa yang dimaksud dalam penelitian ini merupakan siswa kelas X Teknik Instalasi Tenaga Listrik (TITL) di SMK Swasta Imelda Medan. Metode yang digunakan dalam penelitian ini adalah metode penelitian pengembangan (Research and Development). 


\section{HASIL DAN PEMBAHASAN}

Hasil

Desain Awal Media

Tahap ini bertujuan untuk menghasilkan rancangan awal yang akan dikembangkan. Rancangan awal yang dimaksud adalah rancangan seluruh produk berupa desain media pembelajaran interaktif pada materi Teori Kemagnetan mata pelajaran Dasar Listrik Dan Elektronika Kelas X TITL.

Menu dalam media pembelajaran multimedia interaktif lectora inspire ini terdiri dari: (1) Materi (2) Quiz, (3) Video (4) Profil (5) Pustaka (6) Help . Menu materi berisikan informasi terkait dengan pembelajaran pada Teori Kemagnetan. Menu Quiz berisikan soal-soal latihan untuk mengukur tingkat pemahaman siswa tentang materi yang disajikan. Menu Video berisikan Video yang berkenaan dengan materi pembelajaran. Menu Profil berisikan tentang profil singkat pembuat/pengembang media pembelajaran untuk menunjukkan identitas pengembang serta sebagai bukti keaslian dari produk tersebut. Menu Pustaka berisikan ringkasan pembelajaran. Menu Help berisikan bantuan maupun navigasi navigasi yang membantu user menggunakan media pembelajaran.

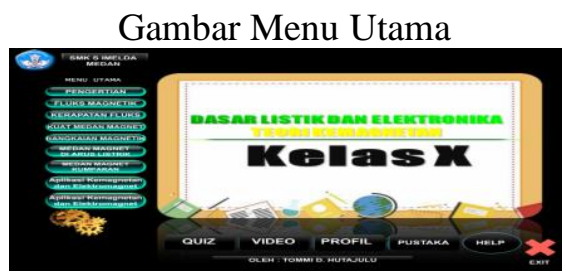

Gambar Grafik Penliaian Ahli Media

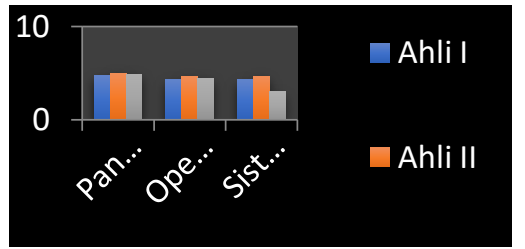

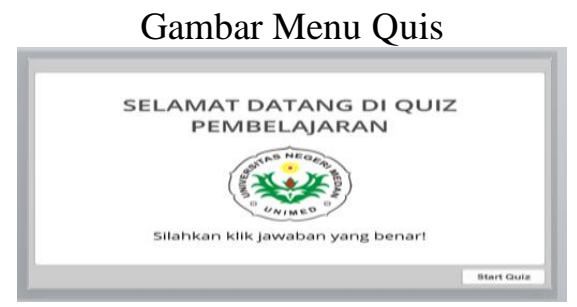

Gambar Grafik Penilaian Ahli Materi

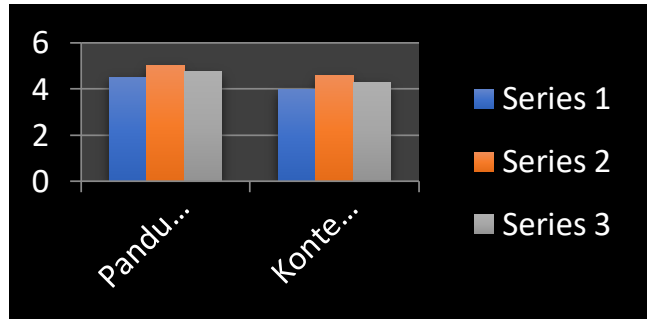

\section{Pembahasan}

Penelitian ini diangkat dari permasalahan karena guru mata pelajaran DLDE lebih sering memberikan penjelasan materi pembelajaran dengan metode ceramah dan tidak adanya bahan ajar yang menjadi pegangan siswa sehingga peserta didik tidak dapat belajar secara mandiri.

Metode yang digunakan pada penelitian ini adalah metode Research and Development (R\&D) dengan model 4D yang dikembangkan oleh S. Thiagarajan, Dorothy S. Semmel, dan Melvyn I. Semmel sebagai desain pembelajarannya. Empat tahapan dalam model ini yaitu pendefinisian (define), perancangan (design), pengembangan (develop), dan penyebaran (dessiminate). Namun dalam prosedur pengembangan media pembelajaran multimedia interaktif Lectora Inspire ini model pengembangan 4D dilakukan sedikit modifikasi, yaitu penyederhanaan dari 4D menjadi 3D sehingga model yang digunakan yaitu pendefinisian (define), perancangan (design), dan pengembangan (develop). Hal ini sesuai dengan tujuan penelitian yaitu untuk dapat mengetahui proses pengembangan dan kelayakan media pembelajaran multimedia interaktif Macromedia Flash pada kelas X TITL SMK Swasta Imelda Medan.

Pada tahap-tahap dari penelitian pengembangan yang telah dilaksanakan, maka dihasilkan suatu pengembangan media pembelajaran yang divalidasi oleh validator yang terdiri dari 2 ahli materi, yaitu Dosen dari Teknik Elektro Universitas Negeri Medan M. Aulia Rahman S, S.T., M.T. dan Drs. Panahatan Sitorus, M.Pd., dan 2 ahli media, yaitu Dosen dari Pendidikan Teknologi Informasi Dan Komputer Universitas Negeri Medan Reni Rahmadani S.Kom dan Fahmi Syahputra S.Kom.,M.Kom. dengan menggunakan instrumen penelitian yang diadaptasi dari Sriadhi (2018). Hasil validasi dari ahli materi dan 
ahli media menunjukkan bahwa media pembelajaran Macromedia Flash layak digunakan/diterapkan dengan sedikit revisi dalam pembelajaran Dasar Listrik kelas X TITL SMK Swasta Imelda Medan dengan dibuktikan pada penjelasan dibawah ini.

Berdasarkan data validasi yang diisi oleh ahli media dan ahli materi sebagai Validator, maka media pembelajaran ini dinyatakan memenuhi persyaratan dan layak digunakan sebagai pembelajaran dengan dibuktikan dengan nilai skor 4,59 dikategorikan "Sangat Layak" dari ahli media dan skor 4,52 dikategorikan "Sangat Layak" dari ahli materi.

Produk yang telah dikambangkan tidak dilakukan uji coba produk kepada peserta didik dikarenakan kondisi pandemi CoVid-19 dan anjuran Pemerintah untuk melakukan kegiatan pembelajaran dirumah. Produk telah divalidasi oleh ahli media dan ahli materi untuk diuji kelayakannya dan penelitian hanya dilakukan sampai pada tahap pengembangan (develop) sesuai dengan tujuan penelitian, yaitu untuk mengetahui kelayakan dari media pembelajaran multimedia interaktif Macromedia Flash.

\section{KESIMPULAN}

Pengembangan media pembelajaran multimedia interaktif Macromedia Flash menggunakan metode penelitian Research and Development (R\&D) dengan model 4D sebagai desain pembelajarannya. Adapun langkah-langkah pada tahapan penelitian model 4D adalah define, design, develop, dan disseminate yang diadaptasi menjadi pendefinisian, perancangan, pengembangan, dan penyebaran. Tetapi tahap penyebaran (dessiminate) tidak dilakukan karena keterbatasan waktu dan pada tahap pengembangan (develop), tujuan penelitian telah tercapai dimana media pembelajaran yang dikembangkan telah diketahui sejauh mana kelayakannya untuk diterapkan dalam proses pembelajaran. Hal ini sesuai dengan tujuan penelitian yaitu untuk mengetahui proses pengembangan media pembelajaran multimedia interaktif Macromedia Flash mata pelajaran Dasar Listrik kelas X TITL SMK Swasta Imelda Medan..Berdasarkan data validasi yang diisi oleh ahli media dan ahli materi sebagai Validator, maka media pembelajaran ini dinyatakan memenuhi persyaratan dan layak digunakan sebagai pembelajaran dengan dibuktikan dengan nilai skor 4,59 (Sangat Layak) dari ahli media dan skor 4,52 (Sangat Layak) dari ahli materi.

\section{DAFTAR PUSTAKA}

Alami, Fikri. (2006). Pembuatan Media Pembelajaran dengan Macromedia Flash MX 2004. Lampung : Universitas Lampung.

Ariani, Niken, Dan Haryanto, Dany. (2010). Pembelajaran Multimedia di Sekolah. Jakarta : Prestasi Pustaka.

Arsyad, Azhar.(2011). Media Pembelajaran. Jakarta : Raja Grafindo Persada.

Baharuddin. (2015). Development Of Learning Media Based E-learning In Vocational High School. International Conference on VocationalEducation and Electrical Enggineering(ICVEE).

Daryanto.(2010). Media Pembelajaran. Bandung: Satu Nusa.

Fathurrohman, M dan Sulistyorini. (2012). Belajar Dan Pembelajaran Meningkatkan Mutu Pembelajaran Sesuai Standar Nasional. Yogyakarta : Teras.

Hosnan, M. (2014). Pendekatan Saintifik dan Konstektual dalam Pembelajaran Abad 21. Bogor. Ghalia Indonesia.

Madcoms. (2006). PHP dan MySQL. Madiun: And 